\title{
Intercultural And Marketing Communication: Challenges and opportunities for Local Advertising Agency
}

\author{
Muhammad Adi Pribadi \\ \{adiposts@gmail.com\} \\ Universitas Tarumanagara, Indonesia
}

\begin{abstract}
In 1960, Indonesia Advertising agency got their attention back from foreign producers. The main factor was the uncertainty of nation's security and political condition after independence until 1966s. At that time, producers of services and goods faced some troubles to sell their products due to Indonesian's purchasing power was in a low rate, besides the nation's security and political condition. Since Suharto became a second president in Indonesia, foreign investors started to join in. However, in 1970s, there were not many advertising agencies. In other hand, it was not easy for producers to choose the right advertising agency, because they would checked an agency based on their portfolios. If an agency had worked with a foreign client, so the agency would have a big chance to work with these foreign producers. This is one of a real sample that happened in 1970. Now days, the conditions become more complex, because local agencies should compete with foreign agencies which had similar cultural background with the foreign producers. Intercultural communication becomes a challege yet an opportunity for the local agencies. how do managers deal with challenges and manage them into opportunities to win the foreign producers? A qualitative methodology with phenomenology was used in this study. The success of local agencies to get foreign producers was because they have workers who have experience in working with foreign agencies. so they realize that it is important to have knowledge about their clients' culture to support their work.
\end{abstract}

KeyWords: Advertising Agency, Intercultural Communication, Marketing Communication

\section{Introduction}

Intercultural communication plays a role in success of business activities [1]. An entrepreneur who applies intercultural communication in his business would lessen a miscommunication with his clients. Advertising agencies are marketing communication business which connecting producers (clients) and consumers.

Advertising agencies need to pay attention to culture that their clients' had in order to succeed their cooperation. Length of the cooperation itself would be determined by the success of advertising agencies themselves to understand their clients' culture [2]. Verdar stated that clients in USA tend to use agencies who are also from USA. They are really proud of their local producers and products. Basically, every groups have ethnocentric attitude and stereotyping [3]

A meeting between clients and advertising agencies hold at creative brief and pitching [4]. In this meeting the client would deliver their reasons for conducting a marketing communication to the invited advertising agencies [5]. After the meeting, the advertising agencies designed concepts of marketing communication that would be presented to their clients based on their appointed time. The presentation of marketing communication concepts 
is called as pitching process [6]. In this process, clients would choose an advertising agency that is considered to have a similar concept with them.

Advertising agencies learn consumers to find out a behavior which describe their culture. Advertising agencies need to see a culture from users' perspectives, so their marketing communication products could be accepted. An effort to learn users' condition is by doing a research. Qualitative and quantitative research methodologies are used by the advertising agencies [7]. Advertisements for consumers in Italy need to show a drama, while advertisements in Scandinavian countries need to consider gender equality [8].

Marketing communication activities that do not consider culture tend to fail to be accepted by market. Victoria's Secret online advertisement offends women in USA and Europe because of the 'the perfect body' words [9].

George Herbert Mead explained in Symbolic Interaction theory that individuals collaboration in a team are determined by thought, self, and society. The thought describes human's ability in manipulating symbols to be able to collaborate with other individual. While self is individual's ability which always puts themselves as a person who is communicating with them. Society is formed when every members create a value which agreed by other individuals to unite. These rules and values are known as generalized others [10].

Symbolic interaction theory explains that every individuals from different culture could collaborate when there is a harmony in a process of symbolic interaction (Significant symbols). They create a community by using the agreed values (West and Turner, 2010) [ ]

Marketing communication business is really dependent on cultural understanding that is owned by both clients and consumers. Advertising agencies who are understanding culture of both clients and consumers would succeed in doing the campaigns. The success of the advertising agencies in handling clients' culture would create a collaboration between the clients and agencies, and the consumers and brand.

\section{Method of Research}

Researcher conducted a research in the oldest advertising agency in Indonesia that is still operating until now. The tight business competition has made local advertising agencies lose from foreign agencies. The researcher chose this local advertising agency because of its ability in facing the tight competition with foreign agencies.

This research used qualitative methodology. Phenomenology is used as a Method in data submission and data analysis. Deep interview is used by researcher to one informant in data submissions. Documents from book which describes advertising agencies' condition are also used to support researcher in data processing.

The informants have position as Chief Operating Officer (COO) and Human Capital Development (HCD). COO plays a role in managing the operational workflow that carried out by his subordinates, such as Account Director, Account Planner, Creative Group Head, and Creative Director. Researcher need information about his experiences in handling foreign clients because $\mathrm{COO}$ is often communicating with them.

The collected data were analyzed by researcher. Analysis results were confirmed by the informant. With the interviewee, researcher arranged four meeting in order to submit and confirm the data. The data analysis result that conducted by researcher could be changed after confirming to the informant. If there is a lack in analysis results, an improvement would be provided by interviewee would be the right data. The informant are people who have many 
experience in running the advertising agency. Therefore, a correction in analysis result became a refinement of this research.

Researcher chose to keep the advertising agency and informants' name as a secret in order to not to disturb their business activities and as the shown data is sensitive.

\section{Language as a Challenge and an opportunity}

The informant is a COO that has experience working in Japan and US Advertising Agency before he works at his recent agency. He also had been pitching with clients from Japan and Europe.

When he delegated his agency to Japan to do pitching with one clients from Japan, at that time, he went with Dentsu Indonesia's delegation. For information, the client is a well known brand in Indonesia.

The interviewee lost from Dentsu Indonesia before the pitching was held. When they both took the same taxi to attend the pitching activity, the Dentsu's delegation was called by the clients. They communicated by using Japanese. The situation became more complex when the clients wanted to talk with the informant by using Japanese, too. However, he could not speak in Japanese, so the communication between clients and the interviewee was failed, even the pitching had not been started yet. It happened because the clients decided to meet with Dentsu Indonesia's delegation only.

Dentsu is advertising agency from Japan which has more than 100 branches in many countries, included Indonesia. Dentsu is more than 100 years old agency. Therefore, this agency has a great knowledge in marketing business communication [12]

The informant's experience in handling the clients from Germany was different with the Japanese client. At that time, he still worked with BBDO Indonesia Branch. BBDO is one of foreign advertising agency which had a branch in Indonesia. He conducted a global pitching for 'Bayer' brand. Its products had distributed in many countries, included Indonesia.

Global pitching, according to informant, means when an advertising agency taken a contract from a client, so the advertising agency would handle the marketing communication in several countries that had been determined before.

\section{Communication Strategy is a Solution}

The failure of informant in handling Japanese client did nkt mean that he could not get clients from Japan. It was proven by some Japanese brands agreed to collaborate with his agency, such as KAO, Honda, and Mandom. To conduct a pitching in Japan, he was absolutely lost due to his inability to speak in Japanese. However, Japanese companies that were based in Indonesia, recruited managers who were Indonesian.

The informant did a communication approach with the Indonesian managers, so he could win contracts with these well known brands. However, during the collaboration, the managers always reminded him to worked hard because their reputation was staked in front of their Japanese bosses.

\section{Discussion}

Language is a main factor of advertising agency' success to collaborate with Japan and Europe companies. Individual's ability in using communication symbols that could be understood by people who involved with the communication, become significant symbols that 
leading to a collaboration [11]. Collaboration that happened between two different organizations, created new values [10].

Communication experience determined the success of advertising agencies in conducting a collaboration with their clients. Communication strategies created because of the informant's experience in handling the clients. When he failed to get the Japanese client, it did not mean that he would be failed in getting another Japanese clients. Communication strategy needs to be arranged in order to get another Japanese clients. The informant made an approach to Indonesian manager as a communication strategy. He did a manipulated symbolic in order to get the contract as also delivered by [10]

\section{Conclusion}

Advertising agency needs to recruit workers who have experiences with foreign agencies. They have experience both in foreign language and communication strategies to get contract with clients. Workers' ability in using foreign language would make it easy to get clients. However, a competent worker not only depending to his ability in using other language, but also his ability in using communication strategies that make the collaboration happened.

\section{References}

[1] Mulyana, Deddy. Pengantar Komunikasi Lintas Budaya. Rosda. Bandung. (2019)

[2] Vardar, Nukhet. Global Advertising: Rhyme or Reason?. London: Paul Chapman Publishing Ltd. (1992)

[3] Samovar, Larry A. Porter, Richard E. \&McDaniel, Edwin. Communication Between Cultures. United States of America : WADSWORTH - Cengage Learning. (2010)

[4] Caemmerer, Barbara. The Planning and Implementation of Integrated Marketing Communication. Marketing Intelligence \& Planning. (2009)

[5] Morrison, Margaret., Haley, Eric., Sheehan, Kim Bartel., Taylor, Ronald E. Using Qualitative Research in Advertising: Strategies, Techniques and Application. United States of America: Sage. (2012)

[6] Belch, George E. \& Belch, Michael A. 2012. Advertising and Promotion: An Integrated Marketing Communication Perspective. Singapore: McGraw-Hill. (2012)

[7] Powell, Helen., Hardy, Jonathan., Hawkin, Sarah., Macrury, Iain. The Advertising Handbook. Routledge. New York. (2009)

[8] Percy, Larry., Elliot, Richard Rossenbaum. Strategic Advertising Management. Great Britain: Oxford University Press. (2012)

[9] Stampler, Laura. Victoria Secret Quietly Changes Controversial 'Body Shaming' Ad. (2014)

[10] Charon, Joel M. Symbolic Interactionism. Pearson Education. New Jersey. 2007.

[11] West, Richard. \& Turner, Lynn H. Introducing Communication Theory: Analysis and Application. New York : McGraw-Hill. (2010)

[12] $\mathrm{s}$ 